\title{
Issues in Teaching Speaking to EFL Learners
}

\author{
Siham BOUZAR \\ English Department, University of Algiers 2, Algeria \\ E-mail: Siham_bouzar@hotmail.com
}

Received: March 20, 2019

Accepted: April 22, 2019 Published: April 24, 2019

doi:10.5296/elr.v5i1.14705

URL: https://doi.org/10.5296/elr.v5i1.14705

\begin{abstract}
Speaking as a skill constitutes a real hurdle to overcome by both the teacher and the learner. In other words, the teacher has to find appropriate procedures to help the learner with while the latter has to find a way to master the language. Thus, this article attempts to highlight the concept of speaking; likewise, it tries to deal with the issues relevant to the appropriate teaching of speaking to learners of English as a foreign language (EFL) such as consciousness-raising strategies and oral error correction.
\end{abstract}

Keywords: EFL teaching, Speaking skills, Consciousness-raising

\section{Introduction}

Language is used in our daily interactions to fulfil many different goals such as communicating information, ideas, beliefs, emotions and attitudes to one another. When using language for communication, both the interlocutor and the addressee are involved in two major processes: transmitting ideas and interpreting the message produced. Thus, developing the oral skill is considered as one of the major building blocks in language learning as it requires a combination of knowledge of the target language with skills and strategies that enable to use it effectively. This skill is also very complicated as it relies not only on the teachers' competence in promoting knowledge and giving feedback on the oral outcome but needs as well the learners' willingness and acceptance of teachers' oral correction to refine their performance.

We deal in this piece of work with the issues related to the teaching of speaking which constitutes a priority for many foreign language learners by looking at the spoken language and highlighting the contrast existing between spoken and written languages. Furthermore, we shed light on teachers' intervention to improve this skill by considering the concept of consciousness-raising, the approaches relevant to the teaching of speaking appropriately as well as oral error corrections implemented in the language classroom.

\section{The Spoken Language}

The Oxford Pocket Dictionary of current English (2009) defines speaking as "the action of 
conveying information or expressing one's thoughts and feelings in spoken language". It is considered as one of the most difficult skills in language learning besides writing, listening and reading ones. According to Tarone (2005: 485), speaking is usually viewed as "the most complex and difficult skill to master".

Thus, the basic idea in any oral interaction is that the speaker has the objective of transmitting his ideas, feelings, attitudes and information to the hearer through speech. However, in such oral communication, any faulty production may lead to mismatches and misunderstandings which could derive from lack of the target language, difference in the background knowledge and socio-cultural diversity Olshtain and Celce-Murcia (2001).

Consequently, in order to ensure proper interpretation by the hearer, Harmer (2001: 269) listed some elements necessary for spoken production. According to him, "the ability to speak fluently presupposes not only knowledge of language features but also the ability to process information and language 'on the spot"'. Likewise, many prerequisites for speaking in another language were suggested by Celce-Murcia and Olshtain (2000) namely knowledge of vocabulary, knowledge of syntax and the ability to use discourse connectors.

In addition, speaking as a skill constitutes a real hurdle to overcome by both the teacher and the learner. In other words, the teacher has to find appropriate procedures to help the learner with while the latter has to find a way to master the language. In this context, Brown and Yule (1983: 25) state: "Spoken language production, learning to talk in the foreign language, is often considered to be one of the most difficult aspects of language learning for the teacher to help the students with". Furthermore, Celce-Murcia and Olshtain (2000: 164) claim that oral communication can be considered as challenging and easy at the same time. On one hand, it requires command of listening and production subskills as vocabulary and pronunciation. On the other hand, one can make oneself understood by adopting communication strategies as repetition and body language.

Therefore, in an attempt to master speaking as a skill, learners have to develop, in addition to the linguistic competence, compensatory strategies. These would consist (according to Harmer, 2001, 2007; Hedge, 2000; Celce-Murcia \& Olshtain, 2000) of paraphrasing, illustrating with examples and explanations to clarify one's ideas. These strategies can be developed by ample exposure to authentic language in the classroom and by implementing intensive practice activities.

In sum, it is obvious that the spoken language is very difficult to acquire; therefore, contrasting spoken and written languages, which will be developed in the next section, constitutes a must to improve EFL learners' conversational competence.

\section{Contrasting Spoken and Written Languages}

Although the speaking skill shares the production process with the writing skill, it is very different from the act of writing. In fact, Cook (1989: 115) claims that:

Spoken language, as has been pointed out happens in time, and must therefore be produced and processed 'on line'. There is no going back and changing or restructuring our words as there is in writing; there is often no time to pause and think, and while we are talking or listening, we cannot stand back and view the discourse in spatial or diagrammatic terms...

Indeed, current literature (Bailey, 2005; Cook, 1989; Nunan, 1993; Lazaraton, 2001; Miller \& 
Weinert, 1998; Van Lier, 1995) indicates that spoken and written languages are different not only in terms of being means of communication but also in terms of the way meaning is conveyed. The terms "spoken language" and "written language" do not refer merely to different mediums but relate to partially different systems of morphology, syntax, vocabulary and the organisation of texts (Miller \& Weinert, 1998). Moreover, meaning according to Bailey (2005: 125) in spoken language is "conveyed in part through the suprasegmental phonemes (including rhythm, stress and intonation), whereas punctuation marks and type fonts convey such information in writing".

Spoken and written languages also differ in terms of the demands they make on the listener or reader. In other words, as speaking happens in real time" unlike reading or writing, it requires the interlocutor; ie, the person we are talking to, to listen, understand and wait to take his/her turn to speak. In this context, Lazaraton (2001) supports this idea by saying that in oral communication many demands are in place such as decoding what is transmitted and thinking at the same time about how to contribute in the conversation.

In addition, Bailey (2005: 125) maintains that the opportunities for the speaker to plan and transmit the message are limited "whereas in most written communication, the message originator has time for planning, editing, and revision”. Furthermore, with written language there is no opportunity for the readers to signal that they do not understand as in face to face interaction in which non verbal behaviour can convey non-understanding (Nunan, 1993). This idea is emphasized by Bailey (2005: 125) where she notes that "verbal interaction typically involves immediate feedback from one's interlocutor, whereas feedback to the authors of written texts may be delayed or nonexistent".

Written language has also certain features that are not shared by spoken language. As signalled by Nunan (1993), both differ in terms of grammar and lexical density. Regarding grammar, written and spoken languages comprise complex clauses; however, they differ in the ways they joined together. As far as lexical density is concerned or what is referred to by Nunan (1993: 11) as "the number of content words per clause, it is highly present in written language than in the spoken one".

From what had been mentioned before, it is clear that spontaneous spoken language differs importantly from the standard written form; thus, it is essential to highlight these main differences existing between spoken and written languages in order to develop EFL learners' spoken skill.

\section{Consciousness-Raising}

English language is so vast and varied that it is hard for a teacher to provide the learners with a precise and comprehensive description of it. Therefore, if learners wish to gain fluency in spoken English, it is essential for them to have exposure to features that are typical of spoken language and that they have time to reflect on these features (Willis \& Willis, 1996: 76). Thus, in order to activate learners' knowledge about spoken grammar forms and make them available for face-to-face talk, it is necessary to raise their awareness about the British and the American spoken grammar features through the implementation of special activities. The latter will, according to Willis and Willis (1996), encourage them to think deeply about examples of language and to infer how language functions. The general term allotted for 
activities of this kind is "consciousness-raising" (Willis \& Willis, 1996: 63) or "awareness-raising activities" (Thornbury, 2008: 41). Besides, Schmidt's (2001) 'Noticing Hypothesis' holds that conscious attention to features of L2 input is the key toachieve learning purposes. In this respect it is necessary to elucidate this concept.

Indeed the term consciousness-raising has been given various definitions. Ellis (2002: 168), for instance, defines it as

"an attempt to equip learners with an understanding of a specific grammatical feature, to develop declarative (describing a rule of grammar and applying it in pattern practice drills) rather than procedural (applying a rule of grammar in communication) knowledge of it.

Likewise, Richards, Platt and Platt (1992) view consciousness-raising as an indirect approach to instruct grammar through form focused activities including drills and grammar explanation where the learner is very active. This view is contrasted with traditional approaches to the teaching of grammar in which the learner is given the grammatical rules directly.

The concept of awareness-raising is adopted from the cognitivist learning theory which rejects the behaviourists view about the learners who are considered as "empty vessels waiting to be filled, and instead credits them with an information processing capacity, analogous to computers" (Thornbury, 2008: 38). In teaching terms, cognitivist theory called for some degree of conscious awareness about the rules of the system. Consequently, it replaced the three-stage PPP model (presentation, practice and production) with one that progresses from "awareness-raising, through proceduralization to autonomy" (Thornbury, 2008: 38).

The main characteristics of consciousness raising activities proposed by Ellis (2002) involve isolating specific linguistic features, explicit rule description, using intellectual effort to understand and articulating the rules describing the grammatical feature. To summarize, in consciousness-raising, learners are required to pay attention, to notice and to understand certain features of language, "but there is no requirement to produce or communicate certain sentence patterns taught" (Widodo, 2006: 124).

There are a variety of ways in which consciousness-raising activities might be achieved. Willis and Willis (1996) listed some steps to achieve them. These include identifying the patterns, classifying them, hypothesising, exploring language cross-linguistically and finally manipulating language to extract the underlying patterns.

In the same context; i.e., applying consciousness-raising activities to the teaching of grammar in the language classroom, Thornbury (2005) outlined, in his examination of the knowledge and skills needed for the students to speak, a three step programme to develop EFL learners' spoken skill involving: "awareness-raising activities; appropriation; and Autonomy" (p. 13). According to the same source, one way to help learners uncover the gaps of their language begins with presenting learners with or letting them discover features of spoken language. After understanding the rules and their use, they can apply them in different spoken genres.

Having dealt with what to develop during the teaching process, we must now turn our attention to how to teach the spoken skill appropriately which is elaborated in the following section. 


\section{Approaches to the Teaching of Speaking}

One way to intervene in the process of language learning is through instruction. As concerns the teaching of conversation in second language programs, current literature (Ellis, 2005; Hedge, 2000; Richards, 1990; Thornbury \& Slade, 2006) indicates that there are two major approaches that can be applied in the teaching of conversation: an indirect approach and a direct one.

\subsection{The Indirect Approach}

In his attempt to deal with the teaching of conversation, Richards (1990: 76-77) makes a distinction between two major approaches aforementioned. According to him, the indirect approach is "an approach in which conversational competence is seen as the product of engaging learners in conversational interaction". In other words, learners can develop their spoken skill via their participation in communicative activities. Moreover, Thornbury and Slade (2006: 275) state that the indirect approach assumes that "learners can acquire conversational competence simply by doing it". Ellis (2005: 725) on his part points out that indirect intervention, with its emphasis on learning through communication, is "likely to result in linguistic knowledge that is deployable (i.e. that learners can actually access when asked to engage in real- life communication)".

The justification for an indirect approach to the teaching of conversation is based on the notion laid out by Krashen and Second Language Acquisition theorists which states that language "can be unconsciously acquired through conversation and exposure to comprehensible input" (Richards, 1990: 77). SLA researchers have argued that learners gradually acquire the rules underlying language through conversation.

However, there exists a certain hesitancy in recommending this instructional approach justified by the fact that it focuses on the form of language and the absence of a clear model to follow when designing a course for indirect intervention.

\subsection{The Direct Approach}

Advocates of the direct approach argue that speaking skills should be taught explicitly via consciousness-raising activities (Hedge, 2000; Richards, 1990; Thornbury, 2008; Thornbury \& Slade, 2006). Richards (1990: 77) for instance stresses the importance of providing learners with opportunities to have conversations. He asserts that the direct approach "involves planning a conversation program around the specific microskills, strategies, and processes that are involved in fluent conversation". Thornbury and Slade (2006: 275) support this idea by indicating that the direct approach "presupposes the need for a form-focused instructional stage at some point in the lesson cycle".

The direct approach to teaching conversation raises learners' awareness of the nature, systems and patterns implemented in conversation as it focuses on techniques introduced in casual conversations. The latter can be applied by involving certain aspects "as strategies for turn-taking, topic control, and repair, conversational routines; fluency; pronunciation; and differences between formal and casual conversational styles" (1990: 79).

Likewise, learners gain knowledge on how and where to make use of certain fixed phrases and expressions that are abundant in spoken English discourse by implementing some aspects of conversation. These, according to Thornbury and Slade (2006: 276), 
may take the form of discourse markers and conversational gambits such as conversationalized ways of opening and closing conversations, of turn-taking, and of back-channelling etc. and they may take the form of conventionalized ways of performing certain speech acts, such as apologizing, requesting and thanking.

To sum up, this section has attempted to explore two major approaches to the teaching of conversation to EFL learners. It is evident that each approach has its properties, and it is not possible to declare that the direct approach is superior to the indirect one or vice versa. Nor is it possible to declare that a focus instruction on one will lead to better learning than another. Consequently, a balance between explicit awareness raising techniques and indirect methods is suitable to provide competent speakers of English. Furthermore, when dealing with teaching speaking, one cannot avoid addressing teachers' intervention while correcting learners' oral performance.

\section{Oral Corrective Feedback}

Learners make errors in oral practice because they are required to produce something in the target language. These studies show that Teachers' correction and attitudes towards correction differ and depend on their views of language teaching. They are also based on their own previous L2 learning experiences. Some teachers refute error correction while others adhere to correct errors. They also demonstrate when correction should be done and how to give feedback.

\subsection{Timing of Correction}

Although many studies demonstrated the effectiveness of error correction, researchers consent that its effectiveness depends on different factors namely the timing of correction. According to Chaudron (1988), it is the teacher who is responsible of determining the appropriate type of correction and the suitable time for that. The latter depends on the teachers' views on language and on the approaches of teaching they rely on. In fact, timing of correction differs from one method of teaching to another.

In the grammar translation method and the audio lingual one, learners receive an immediate correction. Broughton et al. (2003) that immediate feedback is vital for learners as it allows them to know how well they have understood the newly learnt forms. This timing of correction is also supported by the behaviourists who suggest that errors should be corrected as soon as they occur because they may cause fossilization. They consider learning as a habit formation where errors constitute a signal of failure. Belbin et al. (1970) defend the behaviourists' view suggesting that errors inhibit the learning process. In the same frame work, Bartram and Walton (1991: 4) state that "often the spontaneous reaction on hearing an error is to correct immediately". However, some teaching approaches were against immediate correction and indicate that delayed correction or ignorance of errors is the best way to help learners develop their interlanguage.

The communicative language teaching approach refuted the behaviourists' view. The errors in this method are regarded as a natural process through which learners go while acquiring a new language and represent a proof to teachers that learning is taking place. This approach believes that learning a second language is similar to first language acquisition in terms of the mistakes resulting from the process of getting in the language. Yet, this approach suggests 
that errors that prevent the flow of communication should be corrected (Prabhu, 1987; Burt \& Kiparsky, 1972; Corder, 1974; Powell, 1973; Hendrickson, 1978; Truscott, 1996). Thus, communicative language teaching views errors as an essential part of the learning process and not as a negative aspect of learning contrary to the previous approaches. The naturalists also were against correcting oral errors. According to them, they should be ignored because correction affects motivation negatively and disturbs the flow of communication. Therefore, instructing the target language in this approach is very challenging as the teacher is not allowed to interrupt learners while expressing themselves.

Many linguists were in support of delayed correction. Brown (2007) for instance proposes that delayed correction is more suitable for communication activities. Besides, conducting a delayed correction all learners can benefit from the correction. Another linguist who was in favour of delayed correction is Mendelson (1990) who states that in oral production learners should be corrected till they finish interacting in order to avoid interrupting their communication.

Other linguists suggested that the timing of correction depended on different factors. According to Scrivener (1994), the time of correction is based on the goal of the activity. For example, if the objective is accuracy, immediate correction is appropriate; however, if the focus is on fluency, later correction is called for as it "...could kill the activity" (ibid, 111).

\subsection{Strategies for Oral Error Correction}

Different terminologies and classifications were adopted to denote the strategies used when providing feedback on an oral performance. Lyster and Ranta (1997: 46), for example, suggested six types of corrective feedback namely "explicit correction, Recast, clarification request, Metalinguistic feedback, elicitation and repetition".

Explicit correction, according to them, refers to the explicit provision of the correct form. As the teacher provides the correct form, he or she clearly indicates that what the student had said was incorrect. As concerns recast strategy, it is generally implicit and involves the teacher's reformulation of all or part of a student's utterance, minus the error. Concerning clarification request strategy, it refers to problems in connection with either comprehensibility or accuracy, or both. It indicates to students either that their utterance has been misunderstood by the teacher or that the utterance is ill-formed in some way and that a repetition or a reformulation is required. As regards metalinguistic feedback, "it contains either comments, information, or questions related to the well-formedness of the student's utterance, without explicitly providing the correct form" (Lyster \& Ranta, 1997: 47). Elicitation as another type of corrective feedback includes pauses allowing students to fill in the blanks, questions eliciting correct forms, reformulating utterances by students. Repetition, as the last strategy for oral error correction, refers to highlighting the student's erroneous utterance by adjusting its tone or its inflection. It is worth noting in this context that the feedback types aforementioned can be implemented in the language classroom individually or by a combination of more than one strategy.

\section{Conclusion}

Using English language for communication involves two major processes from the part of both the interlocutor and the addressee: transmitting ideas, beliefs, emotions and attitudes to 
one another and interpreting the message produced. Therefore, this study looked at the productive aspect of communication and focused mainly on how to develop EFL learners' spoken performance. Accordingly, this piece of work dealt with the teaching issues relevant to the spoken skill by highlighting the concept of spoken language and the difference existing between the latter and the written one. This work also addressed teachers' intervention to improve EFL learners' outcome as far as this building block is concerned. Thus, it tackled the approaches dealing with the teaching of speaking as well as the strategies adopted by teachers to involve learners in the learning process and correct their oral errors.

\section{References}

Bailey, K. M. (2005). Issues in teaching speaking skills to adult ESOL Learners. NCALL Review, 6, 114-164.

Bartram, M., \& Walton, R. (1991). Correction. A Positive Approach to Language Mistakes Hove: Language Teaching Publication.

Belbin, E., Downs, S., \& Moore, B. (1970). Unlearning and its relationship to age. Ergonomics, 13, 419-427. https://doi.org/10.1080/00140136408930759

Broughton, G., Brumfit, C, Pincas, A., \& Wilde, R. D. (2003). Teaching English as a foreign language. NewYork: Routledge.

Brown, G., \& Yule, G. (1983). Teaching the Spoken Language: an approach based on the analysis of conversational English. Cambridge University Press, UK,

Brown, H. D. (2007). Teaching by Principles. White Plains: Pearson Education.

Burt, M., \& Kiparsky, C (1972). The Gooficonn: A Repair Manual for English. Rowley Massachusetts. Newburg House.

Celce-Murcia, M., \& Olshtain, E (2000). Discourse and Context in Language Teaching. Cambridge University Press, United Kingdom.

Celce-Murcia, M., \& Olshtain, E (2001). Discourse Analysis and Language Teaching. In D. Schiffrin (Ed.), The Handbook of Discourse Analysis (pp. 707-724). Blackwell publishers LTD, United Kingdom.

Chaudron, C. (1988). Second language classrooms: Research on teaching and learning. Cambridge: Cambridge University Press. https://doi.org/10.1017/CBO9781139524469

Cook, G. (1989). Discourse. Oxford University Press.

Corder, S. (1974). I diosyncratic Dialects and Error Analysis. In J. Richard (Ed.), Error Analysis: Perspectives on Second Language Acquisition (pp. 158-171).

Ellis, R. (2002). Grammar teaching-Practice or consciousness-raising? In J. Richards, \& W. Renadia (Eds.), Methodology in language teaching: an anthology of current practice (pp. 167-174). Cambridge: Cambridge University Press.

Ellis, R. (2005). Instructed Language Learning and Task-Based Teaching. In H. Eli (Ed.), 
Handbook of Research in Second Language Teaching and Learning. Lawrence Erlbaum Associates, Inc, Publishers: London.

Harmer, J. (2001). The Practice of English Language Teaching. Longman, Pearson Education Limited, England. https://doi.org/10.1177/003368820103200109

Hedge, T. (2000). Teaching and Learning in the Language Classroom. Oxford University Press.

Hendrickson, J. (1978). Error Correction in Foreign Language Teaching. Recent. theory research and practice. Modern Language Journal, 62(8), 387-98. https://doi.org/10.1111/j.1540-4781.1978.tb02409.x

Lazaraton, A. (2001). Teaching Oral Skills. In M. Celce-Murcia (Ed.), Teaching English as a Second or Foreign Language (3rd ed, pp. 103-115). Boston: Heinle and Heinle.

Lyster, R., \& Ranta, L. (1997). Corrective feedback and learner uptake: Negotiation of form in communicative classrooms. Studies in Second Language Acquisition, 19, 37-66. https://doi.org/10.1017/S0272263197001034

Mendelson, D. (1990). How to correct errors in the communicative language talking class. Prospect, 5(1), 67-83.

Mendez, E. H. (2010). Oral corrective feedback: Some ways to go about it. FEL, 2(1), 25-38.

Miller, J., \& Weinert, R. (1998). Spontaneous Spoken Language: Syntax and Discourse. Clarendon Press, Oxford University Press.

Nunan, D. (1993). An Introduction to Discourse Analysis, Penguin, Harmondsworth, England.

Prabhu, N. S. (1987). Investigating Fluency In ELF: A Quantitative Approach Language Learning.

Richards, J. C. (1990). The Language Teaching Matrix. Cambridge University Press, UK. https://doi.org/10.1017/CBO9780511667152.002

Richards, J., Platt, J., \& Platt, H. (1992). Longman Dictionary of language teaching and Applied Linguistics. London: Longman.

Scrivener, J. (2005). Learning teaching. Oxford: Macmillan.

Tarone, E (2005). Speaking in a Second Language. In H. Eli (Ed.), Handbook of Research in Second Language Teaching and Learning (pp. 485-502). Lawrence Erlbaum Associates, Publishers, London.

Thornbury, S. (2008). How to Teach Speaking. Pearson Education Limited, England.

Thornbury, S., \& Slade, D. (2006). Conversation: From Description to Pedagogy. Cambridge University Press, UK. https://doi.org/10.1017/CBO9780511733123

Truscott, J. (1996). The Case Against Grammar Correction in L2 Writing. Language Learning, 


\section{Macrothink}

46, 327-369. https://doi.org/10.1111/j.1467-1770.1996.tb01238.x

Van Lier, L. (1995). Introducing language awareness. London: Penguin, England.

Weydt, H. (2006). What are Particles Good for? In F. Kerstin (Ed.), Approaches to Discourse Particles. Elsevier Ltd.

Willis, D., \& Willis, J. (1996). Consciousness-raising activities. In D. Willis, \& J. Willis (Eds.), Challenge and Change in Language Teaching (pp. 63-76). Oxford: Heinemann.

\section{Copyright Disclaimer}

Copyright reserved by the author(s).

This article is an open-access article distributed under the terms and conditions of the Creative Commons Attribution license (http://creativecommons.org/licenses/by/3.0/). 